\title{
APLIKASI PORTOFOLIO DALAM PEMBELAJARAN BAHASA ARAB
}

\author{
Muh. Syamsul Ulum
}

\begin{abstract}
ABSTRAK
Untuk mempertahankan irama belajar mahasiswa agar tidak menurun harus terdapat variasi proses dan cara belajar. Dalam hal ini model protofolio sangat efektif untuk mempertahankan irama belajar mahasiswa. Portofolio selain untuk merancang pengajaran juga digunakan untuk evaluasi pengajaran. Sebagaimana diketahui bahwa dalam proses belajarmengajar guru berfungsi sebagai perancang, pelaksana, dan penilai. Dalam fungsinya yang terakhir inilah guru hendaknya melaksanakan dengan baik. Dalamevaluasi proses, pelaksanakan evaluasi dengan cara melihat perkembangan dan kemajuan baik yang bersifat individual maupun kelompok selama proses pembelajaran berlangsung. Hal ini dilakukan dengan cara mencatat perilaku, respon, dan aktivitas mahasiswa dari pertemuan pertama sampai pertemuan terakhir. Sedangkan evaluasi hasil dilakukan dengan cara memberikan tes kepada peserta didik tentang masalah-masalah yang diidentifikasi, kemudian mengoreksi dengan memberikan catatan perbaikan sebagai feedback, selanjutnya mengembalikan hasil koreksian tersebut kepada peserta didik untuk dipelajari guna mempersiapkan tes berikutnya.
\end{abstract}

Kata Kunci : Penilaian, penilaian portofolio

\section{A. PENDAHULUAN}

Untuk mengembangkan potensi siswa diperlukan strategi yang sistematis dan terarah. Hal ini perlu dilakukan karena strategi pengelolaan pendidikan yang ditempuh selama ini, termasukaktualisasi kurikulum dalam pembelajaran, kurang memberikan kebebasan kepada siswa untuk mengembangkan berbagai kemampuan s eperti k ecerdasan intelektual, k ecerdasan e mosional, dan kecerdasan spiritual. Terlebih lagi jika diamati temyata potensi siswa berbedabeda. Kondisi seperti ini memerlukan pengembangan model-model pembelajaran yang mengakomodasi perbedaan potensi dan sekaligus memberikan seluasluasnya untuk secara aktif menumbuhkan kreativitas siswa agar potensinya mampu dikembangkan secara optimal dan proporsional. Untuk itu, perlu 
dikembangkan model pembelajaran aktif yang menitikberatkan pengembangan afek\$i dan perilaku yang didasarkan kebutuhan belajar (learning need based) siswa, dan berdasarkan pengalaman belajar (experiential learning). Karena itu, active learning yang berpusat pada siswa (student centered/participant centered) perlu dikembangkan. Di antara model pembelajaran yang menitikberatkan partisipasi siswa adalah portofolio.

Istilah portofolio memang baru muncul di Indonesia beberapa tahun terakhir ini, namun substansinya sebenamya sudah sering dipraktikkan sejak lama oleh guru-guru meskipun dalam bentuk yang belum sistematis seperti sekarang. Sehingga dapat dikatakan bahwa portofolio sebenarnya barang lama yang dikemas dengan kemasan baru.

Shaklee at. al, (1997:143) menyatakan bahwa "portofolio merupakan sesuatu yang berharga dan merupakan inovasi pendidikan", secara lengkap diungkapkan sebagai berikut:

This is the most worthwhile educational innovation I have done in a long time. A fter twenty-seven years in the classroom, I have finally learned how to use my observations and notes to make better decisions for my students. What else could be more important?

Portofolio merupakan temuan berharga di bidang pendidikan yang ia lakukan selama bertahun-tahun. Setelah 27 tahun di dalam kelas; akhirnya ia mengetahui bagaimana menggunakan pengamatan dan catatan untuk membuat keputusan yang lebih baik bagi siswanya.

Portofolio tidak hanya untuk merancang pengajaran tetapi juga digunakan untuk evaluasi pengajaran. Sebagaimana diketahui bahwa dalam proses belajarmengajar guru berfungsi sebagai perancang, pelaksana, dan penilai. Dalam fungsinya yang terakhir inilah guru hendaknya melaksanakan dengan baik. Evaly asi merupakan unsur pengajaran yang sangat penting karena hanya dengan evaluasi guru dapat mengetahui tingkat perkembangan siswanya dan sekaligus mengetahui sejauh mana keberhasilan pengajaran yang dilakukannya.

Meskipun evaluasi menempati posisi yang sangat penting dalam kegiatan belajar mengajar, banyak guru yang enggan mengadakan evaluasi dengan benar. Banyak guru yang mengajar hanya sekedar m engajar tanpa mengadakan evaluasi untuk mengetahui sejauh mana pengajaran yang dilakukan dimengerti dan dipahami oleh siswa. Banyak faktor yang mempengaruhi mengapa guru enggan m engadakan evaluasi. $\mathrm{D} i$ antaranya a dalah keetika $g$ uru harus mengoreksi pekerjaan siswa. Terlebih jika kita lihat di lapangan banyak guru yang tidak hanya mengajar di satu atau dua sekolahan, melainkan lebih dari itu. 
Bisa dibayangkan betapa sibuknya guru tersebut sehingga mustahil untuk mengoreksi pekerjaan siswanya.

Masalah di atas masih ditambah lagi dengan kurang tepatnya sistem evaluasi yang dilakukan. Banyak guru yang setelah mengajar mengadakan ulangan. Namun hasil ulangan terkadang tidak dinilai dan dikembalikan lagi kepada siswa dengan beberapa catatan umpan balik (feed back). Banyak juga guru yang mengadakan evaluasi hanya di tengah semester dan akhir semester. Cara tersebut tentunya tidak objektif karena siswa belajar dari hari kehari, waktu kewaktu, maka cara evaluasi yang dilakukan haruslah dari waktu ke waktu. Dengan demikian guru dapat dengan objektif mengetahui dan menilai perkembangan kompetensi siswa. Untuk itu, dikembangkan sistem evaluasi yang objektif karena melihat perkembangan kompetensi siswa dari waktu ke waktu. Evaluasi tersebut dikenal dengan istilah penilaian portofolio (portofolio assessment).

Dalam proses belajar-mengajar, portofolio merupakan cara merancang pengajaran dan evaluasi hasil belajar yang bertahap dari waktu ke waktu dalam rangka mengetahui perkembangan kompetensi siswa. Portofolio memerlukan waktu yang lama sebagaimana proses belajar-mengajar itu sendiri. Karena memerlukan waktu yang lama, evaluasi portofolio memerlukan ketekunan, kesungguhan, dan profesionlisme guru yang tinggi sehingga evaluasi dapat mencapai sasarannya dengan baik.

Portofolio dapat digunakan untuk mengevaluasi seluruh mata pelajaran. Sejauh ini, portofolio banyak digunakan oleh guru bahasa, terutama untuk penilaian kompetensi menulis. Namun lambat laun portofolio digunakan juga untuk mengevaluasi mata pelajaran lain. Portofolio memang tidak dirancang khusus untuk mata pelajaran tertentu, malainkan untuk seluruh mata pelajaran.

Masalah yang muncul kemudian adalah bagaimana portofolio dapat digunakan untuk merancang $d$ an mengevaluasi pengajaran bahasa $\mathrm{A}$ rab. Mengingat pentingnya masalah pengajaran dan evaluasi ini, penulis memandang perlu dilakukan penelitian tentang sistem pengajaran dan evaluasi belajar yang objektif yang benar-benar mengetahui perkembangan kompetensi mahasiswa

\section{B. MODEL PORTOFOLIO}

Istilah portofolio memang baru muncul di Indonesia beberapa tahun terakhir ini, namun substansinya sebenamya sudah sering dipraktikkan sejak lama oleh guru-guru meskipun dalam bentuk yang belum sistematis seperti 
sekarang. Sehingga dapat dikatakan.bahwa portofolio sebenarnya barang lama yang dikemas dengan kemasan baru.

Selama ini orang lebih mengenal istilah portofolio dalam lapangan pemerintahan, yakni digunakan untuk menyebut salah satu jabatan menteri, yakni menteri yang tidak memimpin departemen. Dalam bahasa Inggris dikenal istilah minister without portfolio, artinya adalah menteri yang tidak memimpin deparetemen, alia menteri Negara. Dalam lapangan pendidikan dan pengajaran, yang telah dikenal agak luas adalah portofolio sebagai suatu cara penilaian (portfolio based assessment). Sedangkan istilah portofolio sebagai model pembelajaran relatif masih belum dikenal secara luas.

Portofolio sebenamya dapat diartikan sebagai suatu wujud benda fisik, sebàgai suatu proses social pedagogis, maupun sebagai adjective. Sebagai suatu wujud benda fisik, portofolio itu adalah bundel, yakni kumpulan atau dokumentasi hasil pekerjaan peserta didik yang disimpan pada suatu bundel. Misalnya hasil tes a wal (pre-test), t ugas-tugas, catatan a nekdot, piagam penghargaan, keterangan melaksanakan tugas terstruktur, hasil tes akhir (post-test), dan sebdgainya. Sebgai suatu proses sosial pedagogis, portofolio adalah collection of learning experience yang terdapat di dalam pikiran peserta didik baik yang benwujud pengetahuan (kognitif), keterampilan (skill), maupun nilai dan sikap (afektif). Adapun sebagai suatu adjective, portfolio sering kali disbanding dengan konsep lain, misalnya dngan konsep pembelajaran dan penilaian. Jika disandingkan dengan konsep pembelajaran, maka dikenal istilah pembelajaran berbasis portofdolio (portfolio based learning), sedangkan jika disandingkan dengan konsep penilaian, maka dikenal istilah penilaian berbasis portofolio (portfolio based assessment).

Portofolio berarti koleksi dokumen atau tugas-tugas yang diorganisasikan dan dipilih untuk mencapai tujuan dan sebagai bukti nyata dari seseorang yang memiliki pertumbuhan dalam bidang pengetahuan, disposisi, dan keterampilan (Kurikulum Berbasis Kompetensi Mata Pelajaran Kewarganegaraan (Citizenship), SMU, 2001).

Shaklee at. al, (1997:143) menyatakan bahwa "portofolio merupakan sesuatu yang berharga dan merupakan inovasi pendidikan", secara lengkap diungkapkan sebagai berikut:

This is the most worthwhile educational innovation I have done in a long time After twenty-seven years in the classroom, I have finally leamed how to use my observations and notes to make better decisions for my students. What else could be more important? 
Portofolio merupakan temuan yang sangat berharga di bidang pendidikan. Setelah dua puluh tujuh tahun mengajar, akhimya saya mengetahui bagaimana menggunakan pengamatan dan catatanku untuk membuat keputusan yang lebih baik bagi siswaku.

Sedangkan Paulson dan Meyer (1991) mendifinisikan portofolio sebagai:

A purposeful collection of student work that exhibit the student's efforts, progress and achievements in one or more areas. The collection must include st udent participation in selecting contents, the criteria for selection, the criteria for judging merit and evidence of student selfreflection.

Portofolio merupakan sebuah kumpulan karya siswa yang memiliki tujuan menunjukkan usah siswa, perkembangan dan prestasi siswa dalam satu bidang atau lebih. Kumpulan tersebutharus melibatkan siswa dalam memilih isi, criteria pemilihan, dan kriteria penilaian.

Portofolio tidak hanya untuk merancang pengajaran tetapi juga digunakan untuk evaluasi pengajaran. Sebagaimana diketahui bahwa dalam proses belajarmengajar guru berfungsi sebagai perancang, pelaksana, dan penilai. Dalam fungsinya yang terakhir inilah guru hendaknya melaksanakan dengan baik. Evaluasi merupakan unsur pengajaran yang sangatpenting karena hanya dengan evaluasi guru dapat mengetahui tingkat perkembangan siswanya dan sekaligus mengetahui sejauh mana keberhasilan pengajaran yang dilakukannya.

Dari berbagai penjelasan di atas, Dasim (2003) menyimpulkan bahwa portofolio merupakan kumpulan pekerjaan peserta didik dengan maksud tertentu dan terpadu yang diseleksi menurut panduan-panduan yang ditentukan. Panduanpanduan ini beragam tergantung pada mata pelajaran dan tujuan penilaian portofolio itu sendiri. Portofolio biasanya merupakan karya terpilih dari seorang siswa. Tetapi dapat juga berupa karya terpilih dari satu kelas secara keseluruhan yang bekerja secara kooperatif membuat kebijakan untuk memecahkan masalah.

Istilah "karya terpilih" merupakan kata kunci dari portofolio. Maknanya adalah bahwa yang harus menjadi akumulasi dari segala sesuatu yang ditemukan para siswa dari topik mereka harus memuat bahan-bahan yang menggambarkan usaha terbaik siswa dalam mengerjakan tugas-tugas yang diberikan kepadanya, serta mencakuppertimbangan terbaiknya tentang bahan-bahan mana yang paling penting. Oleh karena itu, portofolio bukanlah kumpulan bahan-bahan yang asal comot dari sana sini, tidak ada relevansinya satu sama lain, ataupun bahan yang tidak memperlihatkan signifikansinya sama sekali. 


\section{Prinsip Dasar Portofolio}

Jika diamati secara seksama, sekurang-kurangnya ada lima prinsip dasar yang di bawakan model pembelajaran portofolio ini. Kelima prinsip dasar yang dimaksud adalah prinsip belajar siswa aktif (student active learning), kelompok belajar k ooperatif (cooperative learning), pembelajaran partisipatorik, mengajar yang reaktif (reactive teaching), dan prinsip belajar yang menyenangkan (joyfull learning). Prinsip-prinsip tersebut dijelaskan sebagai berikut.

\section{a. Prinsip Belajar Siswa Aktif (student active learning)}

Proses pembelajaran d engan menggunakan Model Pembelajaran Berbasis Portofolio berpusat pda siswa. Dengan demikian model ini menganut prinsip belajar siswa aktif. Aktivitas siswa hampir di seluruh proses pembelajaran, dari mulai fase perencanaan di kelas, kegiatan lapangan, dan pelaporan.

Dalam fase perencanaan aktivitas siswa terlihat pada saat mengidenfikasi masalah dengan menggunakan teknik burse ide (brain strorming). Setiap siswa boleh menyampaikan masalah yang menarik baginya, di samping tentu saja yang berkaitan dengan materi pelajaran. Setelah masalah terkumpul, siswa melakukan voting untuk memilih satu masalah untuk kajian kelas:

Dalam fase kegiatan lapangan, aktivitas siswa lebih tampak. Dengan berbagai teknik misalnya dengan wawancara, pengamatan, kuesioner, dan lainlain. Mereka mengumpulkan data $d$ an informasi y ang diperlukan untuk menjawab permasalahan yang menjadi kajian kelas mereka. Untuk melengkapi data dan informasi tersebut, mereka mengambil foto, membuat skets, membuat kliping, bahkan ada kalanya mengabdikan peristiwa penting dalam video.

Pada fase pelaporan aktivitas mereka terfokus pada pembuatan portofolio kelas. Segala bentuk data dan informasi disusun secara sistematis dan disimpan pada sebuah bundel (portofolio seksi dokumentasi). Adapun data dan informasi yang paling penting dan menarik (eyes catching) ditempel pada portofolio seksi penanyangan, yaitu papan panel yang terbuat dari kardus bekas atau bahan lainyang tersedia. Setelah portofolio selesai dibuat, dilakukanlah public hearing dalam kegiatan show-case dihadapanb dewan juri. Kegiatan ini merupakan puncak penampilan siswa, sebab segala jerih payah siswa diuji dan diperdebatkan di hadapan dewan juri. 


\section{b. Kelompok Belajar Kooperatif (cooperative learning)}

Proses pembelajaran dengan model ini juga menerapkan prinsip belajar kooperatif, yaitu proses pembelajaran yang berbasis kerjasama. Kerja sama antarsiapa? Tiada lain adalah kerja sama antarsiswa dan antar komponenkomponen lain di sekolah, termasuk kerjasama sekolah dengan orang tua siswa dan lembaga terkait. Kerja sama antarsiswa jelas terlihat pada sat kelas sudah memilih satu masalah untuk bahan kajian bersama. Semua pekerjaanm disusun, orang-orangnya ditentukan, siapa mengerjakan apa, merupakan satu bentuk kerjasama itu.

Dengan komponen-komponen sekolah lainnya juga sering kali harus dilakukan kerja sama. Misalnya pada saat para siswa hendak mengumpulkan data dan informasi lapangan sepulang dari sekolah, bersamaan waktunya dengan jadwal latihan olah raga di sekolah. Dalam hal ini perlu dicari jalan keluamya, yakni membicarakannya dengan guru olah raga sekolah. Apakah jadwal latihan olah raga yang diundur atau kunjungan lapangan yang diubah. Kasus seperti itu memerlukan kerja sama, walaupun dalam lingkup kecil dan sederhana. Hal serupa juga sering kali terjadi dengan pihak keluarga. Orang tua perlu juga diberi pemahaman, manakala anaknya pulang agak terlambat dari sekolah karena melakukan kunjungan lapangan terlebih dahulu. Sekali lagi, dari peristiwa ini pun tampak perlunya kerja sama antara sekolah dengan orang tua dalam upaya membangun kesepahaman.

Kerja sama dengan lembaga terkait diperlukan pada saat para siswa merencanakan mengunjungi lembaga tertentu atau meninjau suatu kawasan yang menjadi tanggung jawab lembaga tertentu. Misalnya mengunjungi dinas perpakiran untuk mengetahui kebijakan mengenai perpakiran. Mengunjungi kantor bupati atau wali kota untuk mengetahui kebijakan mengenai penertiban pedagang kaki lima. Mengamati dampak pembuangan limbah pabrik pada suatu kawasan tertentu, dan sebagainya. Kegiatyan para siswa itu tentu saja perlu dibekali surat pengantar dari kepala sekolah selaku penanggung jawab kegiatan sekolah.

\section{c. Pembelajaran partisipatorik}

Model Pembelajaran Berbasis Portofolio juga menganut prinsip dasar pembelajaran partisipatorik, sebab melalui model ini siswa belajar sambil melakoni (learning by doing). Salah satunya bentuk pelakonan itu adalah siswa belajar hidup berdemokrasi. M engapa terdapat $\mathrm{p}$ elakonan hidup 
berdemokrasi? Sebab dalam tiap langkah dalam model ini memiliki makna yang ada hubungannya dengan praktek hidup berdemokrasi.

Sebagai contoh pada saat memilih masalah untukkajian kelas memiliki makna bahwa siswa dapat menghargai dan menerima pendapat yang didukung suara terbanyak. $P$ ada saat berlangsungnya perdebatan, $s$ iswa belajar mengemukakan pendapat, mendengarkan pendapat orang lain, menyampaikan kritik dan sebaliknya belajar menerima kritik, dengan tetap berkepala dingin. Proses ini mendukung adigium yang menyatakan bahwa "democracy is not heredity but learning"'(demokrasi itu tidak diwariskan, tetapi dipelajari dan dialami). Sebab dalam kenyataannya tidak ada jaminan anak dari seorang ayah yang democrat akan menjadi seorang democrat pula. Yang mungkin terjadi adalah seorang ayah yang democrat, mendidik dan membina anaknya tentang hidup berdemokrasi dalam suasana pergaulan yang demokritis, sehingga pada suatu ketika ia menjadi seorang democrat pula. Dengan demikian, menjadikan seorang democrat harus melalui proses pendidikan yang demokratis pula.

Oleh karena itu mengajarkan demokrasi itu harus dalam suasana yang demokratis (teaching democracy in and for democracy). Tujuan ini hanya dapat dicapai dengan belajar sambil melakoni atau dengan kata lain harus menggunakan prinsip belajar partisipatorik.

\section{d. Reactive Teaching (reactive teaching)}

Untuk menerapkan model pembelajaran berbasis portofolio, guru perlu menciptakan strategi yang tepatagar siswa memiliki motivasi belajar yang tinggi. Motivasi yang tinggi akan dapat tercipta jika guru dapat meyakinkan siswa akan kegunaan materi pelajaran bagi kehidupan nyata. Guru juga harus dapat mencipotakan situasi sedemikian rupa sehingga materi pelajaran selalu menarik, tidak membosankan. Guru harus memiliki sensitivitas yang tinggi untuk segera mengetahui apakah kegiatan pembelajaran sudah membosankan siswa. Jika hal ini terjadi, guru harus segera mencari cara untuk mengubahnya. Inilah tipe guru yang reaktif.

Guru yang reaktif di antaranya apat dilihat dari beberapa hal sebagai berikut:

- Menjadikan siswa sebagai pusat kegiatan belajar.

- Pembelajaran dimulai dengan hal-hal yang sudah diketahui dan dipahami siswa. 
- Selalu berupaya membangkitkan mootivasi belajar siswa dengan membuat materi pelajaran sebagai sesuatu hal yang menarik dan berguna bagi kehidupan siswa.

- Segera mengenali materi atau metode pembelajaran yang membuat siswa bosan. Bila hal ini ditemui, ia segera menanggulanginya.

Model pembelajaran berbasis portofolio menyaratkan guru yang reaktif, sebab tidak jarang pada awal pelaksanaan model ini, siswa ragu dan bahkan malu untuk mengemukakan pendapat. Hal tersebut terjadi oleh karena secara empirik potensi dan kemampuan siswa bervariasi. Ada siswa yang sudah terbiasa mengemukakan pendapat, berdiskusi, bahkan berdebat, akan tetapi siswa yang lain banyak yang tidak demikian. Dalam keadaan seperti itu, guru hendaknya dapat memberikan dorongan dan motivasi. Caranya adalah dengan memberikan p enghargaan kepada setiap pendapat $s$ iswa $b$ agaimanapun kualitasnya. Jika setiap pendapat siswa dihargai, lama- kelamaan pada diri mereka muncul kepercayaan dirinya untuk tidak malu-malu lagi mngemukakan pendapat.

\section{e. Prinsip Dasar Belajar yang Menyenangkan (joyfull learning).}

Salah satu teori belajar menegaskan bahwa sesulit apapun materi pelajaran apabila dipelajari dalam suasana yang menyenangkan pelajaran tersebut akan mudah dipahami. Sebalaiknya walaupun materi pelajaran tidak terlampau sulit untuk dipelajari, namun apabila suasana belajar membosankan, tidak menarik, apalagi siswa belajar di bawah tekanan, maka pelajaran akan sulit dipahami. Atas dasar pemikiran tersebut, maka agar para siswa mudah memahami materi pelajaran, mereka harus belajar dalam suasana yang menyenangkan, penuh daya tarik dan penuh motivasi.

Model Pembelajaran Berbasis Portofolio menganut prinsip dasar bahwa belajar itu harus dalam suasana yang menyenangkan (joyfull learning). Melalui model ini para siswa diberi keleluasaan untukmemilih tema belajar yang menarik bagi dirinya. Misalnya kelas yang sedang mempelajari bahasa merencanakan membuat proyek belajar, yaitu mengidentifikasi sejumlah masalah aktual yang ada di masyarakat, kemudian memilih salah satu di antaranya untuk bahan kajian kelas. Fase selanjutnya mereka terjun ke masyarakat mencari data dan informasi untuk memecahkan masalah tersebut. Pengalaman terjun ke masyarakat adalah salah satu pengalaman belajar riil yang menyenangkan bagi mereka, di samping melatih sejumlah kompetensi untuk hidup bermasyarakat, seperti misalnya memiliki kemampuan melakukan wawancara, melakukan 
observasi membuat laporan perjalanan, mampu bergaul dengan masyarakat, menyelami aspirasi mereka, dan sebagainya. Kompetensi-kompetensi tersebut kelak di kemudian hari sangat bermanfaat bagi para siswa untuk hidup di masyarakat. Hal yang perlu diingat adalah bahwa pada hakikatnya pendidikan dilakukan untuk membuat siswa siap menghadapi hidupnya.

\section{Portofolio sebagai Proses Belajar Mengajar (Portofolio Based Learning)}

Portofolio sebagai proses belajar mengajar diawali oleh isu/masalahyang memerlukan suatu pemecahan (problem solving). Wujudnya suatu tampilan yang dituangkan pada panel atau poster berukuran kurang lebin $100 \mathrm{~cm}$ yang berasal dari kardus/papan/gabus/steroform yang pada umumnya berbentuk segi empat sama sisi (bujur sangkar) berjajar, dan dapat berdiri tanpa penyangga. Namun tidak m enutup kemungkinan berbentuk lain s esuai dengan daya keatifitas siswa, dengan syarat tetap komunikatif. Portofoilio sebagai proses belajar dilakukan secara kelompok.

Dengan demikian, yang dimaksud portofolio di sini adalah suatu kumpulan pekerjaan siswa dengan maksud tertentu dan terpadu yang diseleksi menurut panduan-panduan yang ditentukan. Panduan-panduan ini beragam tergantung pada mata pelajaran dan tujuan penilaian portofolio. Biasanya portofolio merupakan karya terpilih dari seorang siswa, tetapi dalam model pembelajaran ini setiap portofolio berisi karya terpilih dari satu kelas secara keseluruhan yang bekerja secara kooperatif memilih, membahas, mencari data, menganalisis, dan mencari pemecahan terhadap suatu masalah yang dikaji.

Setiap portofolio harus memuat bahan-bahan yang menggambarkan usaha erbaik siswa dalam mengerjakan tugas-tugas yang diberikan kepadanya, serta mencakup pertimbangan terbaiknya tentang bahan-bahan mana yang paling penting untuk ditampilkan. Tampilan portofolio berupa tampilan visual dan audio yang disusun secara sistematis, melukiskan proses berfikir yang didukung oleh seluruh data yang relevan. Secara u tuh melukiskan "integrated learning experience" atau pengalaman belajar yang terpadu dan dialami oleh siswa dalam kelas sebagai suatu kesatuan.

Strategi pembelajaran (instruksional strategy) yang digunakan dalam model ini, pada dasarnya bertolak dari strategi inquiry learning, discovery learning (belajar penemuan), problem solving learning (belajar memecahkan masalah), dan research oriented learning (belajar mengamati) yang dikemas dalam model "Project" oleh John Dewey.

Portofolio sebagai PBM ini terbagi dalam dua bagian yakni: 


\section{1) Portofolio Tampilan}

Portofolio tampilan pada umumnya berbentuk papan empat muka berlipat kurang lebih berukuran $100 \mathrm{~cm}$, namun tidak menutup kemungkinan berbentuk lain sesuai daya kreatifitas siswa, dengan syarat tetap komunikatif. Bentuk lain tersebut seperti segi tiga sama sisi, lingkaran, oval ataupun bentuk-bentuk lainnya yang secara berurutan menyajikan:
a. rangkuman permasalahan yang dikaji
b. berbagai alternatif untuk mengatasi masalah
c. usulan kebijakan untuk mengatasi masalah
d. membuat rencana tindakan.

\section{2) Portofolio Dokumentasi}

Portofolio dokumentasi dikemas dalam map ordener, file atau sejenisnya yang disusun secara sistematis mengikuti urutan/langkah-langkah portofolio tampilan. Portofolio tampilan dan dokumentasi selanjutnya disajikan dalam suatu simulasi atau dengar pendapat (public hearing) yang dapat menghadirkan pejabat setempat yang terkait dengan masalah yang dikaji. Acara dengar pendapat dapat dilakukan di masing-masing kelas atau dalam suatu acara "show case" atau "gelar kemampuan/kasus" bersama dalam suatu acara sekolah, misalnya di akhir triwulan atau akhir semester. Bila dikendaki, arena "show case" tersebut dapat pula dijadikan arena "contest" atau kompetisi untuk memilih kelas portofolio terbaik, dan selanjutnya dikirim ke dalam "show case and contest" antarsekolah dalam lingkungan kota/kabupaten, propinsi atau bahkan ke tingkat nasional.

\section{Portofolio Penilaian (Assessment Based Portfolio)}

Suatu penilaian selalu berkaitan antara mengajar dan belajar. Dalam portofolio penilaian, guru dalam kelas adalah pasangan suatu tim, siswa bekerja dengan guru unutk menetapkan tujuan pembelajaran. Guru adalah seseorang yang memberikan bantuan, memimpin, dan memberi petunjuk, tetapi guru bukan. sebagai pusat (guru sentris) melainkan siswalah yang menjadi pusat dalam proses belajar mengajar (siswa s entris). Siswa diberi kesempatan untuk berpartisipasi dalam mengambil keputusan yang didasari oleh pengetahuan dan keaktifannya sebagai anggota masyarakat.

Portofolio penilaian (assessement) merupakan koleksi sistematis dari siswa dan guru untuk menguji proses dan prestasi belajar. Portofolio bukan 
objek, melainkan perantara penilaian oleh siswa dan guru yang menggambarkan aktifitas dan proses, yaitu memilih, membandingkan, berbagi pengetahuan, mempertimbangkan/merenungi, membuat keputusan, dan tidak hanya mempertanggungjawabkan apa yang telah dilakukan tetapi juga menguatkan dengan argumentasi yang tepat. Hal ini sesuai dengan pembelajaran merekonstruksi untuk menunjukkan apa yang mereka ketahui, mengerti, dan lakukan; semua itu penting untuk keaktifan penilaian.

Portofolio penilaian merupakan pengajaran praktek (melakukan) dan mempunyai beberapa standar perencanaan yang kuat, yakni mendorong adanya interaksi a ntarlingkungan terkait s eperti interaksi a ntarsiswa, guru, $d$ an masyarakat yang saling melengkapi, serta menggambarkan belajar siswa secara mendalam, yang pada akhimya dapat membantu siswa menjadi sadar untuk meningkatkan dirinya sebagai pembaca dan penulis yang baik.

Rencana dan implementasi pembelajaran ini, menggunakan waktu-waktu untuk belajar, waktu untuk praktek, melakukan, dan melatih. Waktu untuk melakukan pendidikan (pembelajaran) tidak terasa seperti jika mereka menerima pelajaran secara konvensional, apalagi jika siswa mempunyai kemauan dan kemampuan untuk memperluas wawasannya sehingga siswa memperoleh kecakapan yang lebih baik. Akhimya para siswa, anggota keluarga, orang tua, dan lebih penting lagi guru mempunyai keyakinan akan kebaikan-kebaikan dalan pelaksanan portofolio.

Portofolio penilaian ini dapat dilakukan selama periode tertentu, misalnya portofolio penilaian bulanan, triwulan (tengah semester), semester, maupun tahunan; tergantung dari program dan kebutuhan guru dan siswa. Tetapi biasanya penilaian dilakukan guru berkaitan dengan waktu pembagian rapor, karena guru dalam memberikan penilaian berdasarkan hasil ulangan (tes) saja, baik formatif maupun sumatif.

\section{Langkah-langkah Penerapan Penilaian Portofolio}

Lebih jauh Kemp dan Toperof (2001) menjelaskan langkah-langkah penerapan portofolio. Secara umum, langkah-langkah tersebut dapat dibedakan ke dalam empat tahap, yakni tahap persiapan, pelaksanaan, penilaian, dan tindak lanjut (follow up).

\section{1) Tahap Persiapan}

Menentukan tujuan portofolio. Dalam menentukan tujuan portofolio, guru berpatokan pada kurikulum yang berlaku. Tujuan haruslah ditentukan 
terlebih dahulu agar portofolio yang dilaksanakan selalu mengarah untuk mencapai tujuan tersebut.

b. Mengenalkan portofolio kepada siswa. Agar siswa memiliki ketertarikan terhadap portofolio, guru memberikan penjelasan tentang portofolio baik mengenai pengertian, ruang lingkup, tujuan, dan cara mengerjakannya. Dengan mengenal portofolio dan tujuannya diharapkan siswa memiliki semangat dalam melaksanakan setiap tugas portofolio.

c. Menentukan isi portofolio. Tidak setiap unit materi pelajaran harus dimasukkan ke dalam materi portofolio karena terbatasnya waktu dan sulitnya mengontrol. Untuk materi yang perlu pengembangan dan tidak mungkin diselesaikan di dalam kelas yang cocok untuk dimasukkan ke dalam materi portofolio.

d. Memberikan petunjuk pelaksanaan portofolio. Agar pelaksanaan tugas portofolio sesuai dengan yang diharapkan, guru menjelaskan petunjuk pelaksanaanya. Dalam memberikan petunjuk pelaksanaan disampaikan juga kriteria penilaian agar siswa mengerjakan tugas dengan sebaik mungkin untuk mendapatkan nilai yang bagus. Hal ini penting karena tugas yang tidak jelas petunjuk pelaksanaanya dan kriteria penilaiannya hanya akan membuat siswa bingung.

\section{2) Tahap Pelaksanaan}

Setiap portofolio dilaksanakan sesuai dengan tujuan masing-masing. Karena t ujuan dan petunjuk telah ditentukan di awal, maka pelaksanaan portofolio menjadi lebih mudah. Dalam pelaksanaan portofolio, guru terkadang memberikan tugas kelompok. Tugas kelompok ini biasanya bersifat pengamatan dan lebih berat. Tugas individu biasanya lebih ringan dan berhubungan langsung dengan perkembangan pengetahuan siswa. Beberapa tugas individu diselesaikan di dalam kelas untuk mengetahui keaslian karya siswa.

\section{3) Tahap Penilaian}

Pada tahap penilaian, guru mengoreksi karya setiap siswa sesui dengan fokus penugasan. Penilaian tidak selamanya dilakukan oleh guru melainkan juga oleh siswa secara bertukaran. Ketika penilaian dilakukan oleh siswa guru memberikan beberapa petunjuk kriteria penilaian. Dengan demikian dapat dihindarkan sikap subjektif siswa. Setelah sebuah karya dikoreksi dan dinilai, guru memberikan cacatan kecil sebagai umpan balik kepada siswa. Catatan 
terse but berisi komentar tentang kelebihan dan kekurangan karya tersebut. Dengan demikian siswa mengetahui kekurangan dan kesalahannya sehingga mampu memperbaikinya di kemudian hari. Hal ini sengaja dilakukan untuk menumbuhkan motivasi pada diri siswa untuk membuat karya yang lebih baik lagi.

\section{4) Tahap Tindak Lanjut}

Pada tahap ini guru membuat rencana untuk mengadakan lomba karya terbaik baik individu maupun kelompok. Lomba ini biasanya diadakan di akhir semester bersamaan dengan acara lomba antarkelas (meeting class). Karyakarya yang dilombakan meliputi artikel, kliping, laporan, hafalan, dan sebagainya. Pada semester genap, lomba biasanya diadakan sehari sebelum kenaikan kelas. Dengan demikian siswa merasa bahwa usaha kerasnya dihargai dan dikritisi sehingga mampu menambah motivasi belajar yanglebih keras lagi untuk menjadi yang terbaik.

\section{Kelebihan-kelebihan Penilaian Portofolio}

Berikut ini dapat dicatat beberapa alasan mengapa guru menggunakan penilałan portofolio, yakni:

a Penilaian portofolio sesuai dengan tujuan pengajaran. Karya siswa yang dinilai adalah karya siswa yang diajarkan di dalam kelas dan tidak terpisah dari aktivitas kelas seperti tes.

b. Penilaian portofolio memiliki tujuan yang jelas. Tujuan portofolio telah ditentukan di awal.

c. Penilaian portofolio memberikan gambaran tentang kopetensi siswa, baik kedalaman, keluasan, maupun perkembangannya.

d Penilaian portofolio dapat digunakan untuk mengevaluasi berbagai ragam keterampilan baik lisan maupun tulis.

e Penilaianportofolio membangkitkan kesadaran belajar mandiri dan aktif (self-learning and a ctive-learning). Siswa d apat merefleksi d iri tentang perkembangan kemampuannya.

f. Penilaian portofolio melayani setiap siswa dalam kelas yang heterogen.

g Penilaian portofolio mengembangkan keterampilan sosial. Dalam Penilaian portofolio siswa ju8ga diberi tugas untuk mengerjakan tugas di samping individual juga dalam kelompok. 
h. Penilaian portofolio dapat meningkatkan m otivasi belajar untuk meraih tujuan.

i. Penilaian portofolio cara yang efisien dalam menunjukkan kemampuan.

j. Penilaian portofolio memberikan kesempatan bagi dialog antara guru dan siswa.

\section{APLIKASI PORTOFOLIO DALAM PEMBELAJARAN BAHASA ARAB}

\section{Implementasi Model}

Model pembelajaran berbasis portofolio dapat dijadikan proyek belajar para mahasiswa yang sedang mempelajari bahasa Arab di perguruan tinggi. Proyek belajar ini dapat dilaksanakan setiap semester atau setiap tahun sekali, sebagai selingan proses belajar di dalam kelas. Esensinya bahwa melalui model ini lingkungan belajar, yakni keluarga dan masyarakat dijadikan laboratorium secara terpadu, yakni melibatkan keluarga dan masyarakat sebagai sumber belajar.

Berdasarkan sejumlah hasil penelitian dalam bidang proses pembelajaran diyakini bahwa untuk mempertahankan irama belajar mahasiswa agar tidak menurun harus terdapat variasi proses dan cara belajar. Belajar selama satu semester di dalam kelas tanpa adanya selingan, misalnya melakukan kerja lapangan, melakukan out bond, dan sebagainya tentu akan membosankan. Apabila mahasiswa sudah merasa bosan dalam belajar, karena tidak ada variasi dan selingan, maka irama belajar peserta didik akan menurun. Model protofolio dalam mempertahankan irama belajar mahasiswa dapat digambarkan sebagai berikut:

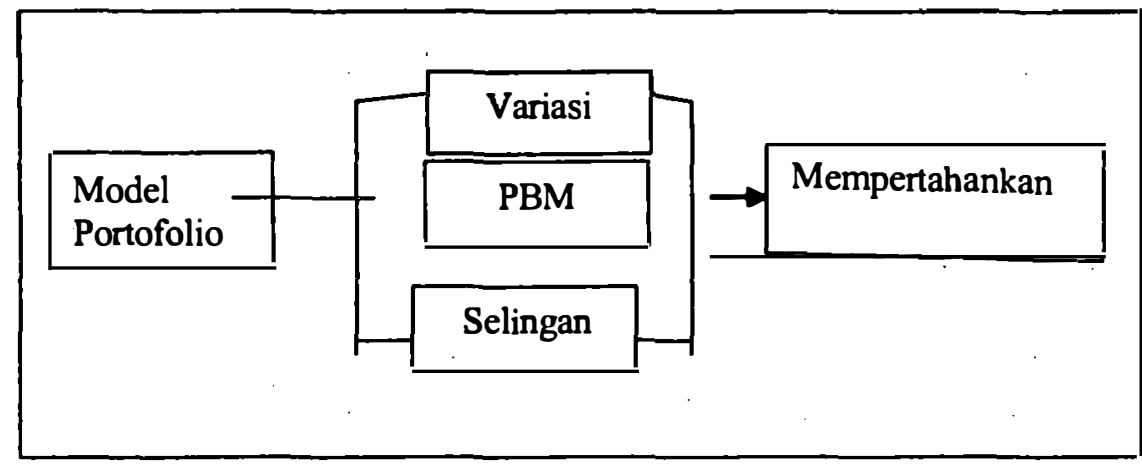


2. Langkah-langkah Pembelajaran

\section{1) Identfikasi Masalah}

Langkah awal y ang dilakukan d alam i dentifikasi masalah a dalah pembentukan kelompok kecil yang mendiskusikan masalah menulis dalam bahasa Arab. Untuk mengerjakan tugas ini, seluruh peserta didik diberi tugas menelaah materi pembelajaran bahasa Arab yang sudah diajarkan selanjutnya mendiskusikan poin-poin yang dianggapnya sulit dan perlu mendapatkan penanganan segera. Dosen/guru membagi peserta didik menjadi 5 (enam) kelompok, setiapkelompoknya terdiri atas 6 (enam) mahasiswa. Setiap kelompk diminta untuk mencari satu masalah lalu mendiskusikannya dalam kelompok kecil tersebut untuk menjawab pertanyaan tersebut.

Tugas mahasiswa yang tengah mempelajari bahasa Arab, adalah belajar memecahkannya dengan menggunakan konsep-konsep bahasa..

Untuk dapat memecahkan masalah dengan baik, selanjutnya setiap mahasiswa diharuskan untuk mencari informasi yang sesuai dengan permasalahan kelompoknya. Pencarian informasi tersebut bisa dilakukan dengan cara membaca buku-buku y ang berkaitan dengan masalah yang akan dipecahkan, atau menanyakannya kepada para ahli, dalam hal ini para dosen yang berkompeten. Setelah mereka menemukan informasi yang cukup, mereka membawa bahan-bahan yang diperoleh ke kelas, selanjutnya memberikan bahan tersebut kepada dosen/guru dan teman sekelas untuk diperiksa dan dipertimbangkan. Dengan membawa bahan-bahan tersebut ke kelas akan mendatangkan keuntungan ganda. Pertama, bagi kawan-kawan lain akan menambah pengetahuan. Kedua, bagi mereka sendiri a kan memperoleh tanggapan yang positif untuk lebih memahami masalah yang sedang dianalisis.

\section{2) Memilih Masalah Untuk Kajian Kelas}

Setelah kelas memiliki cukup informasi tentang masalah-masalah yang akan dikaji, maka langkah selanjutnya adalah membuat daftar masalah dan menentukan salah satu di antaranya untukbahan kajian kelas: Setiap kelompok kecil yang telah selesai mengidentifikasi dan menganalisis masalah dengan dukungan informasi yang memadai, menetapkan satu masalah dan menuliskannya dalam daftar masalah. Selanjutnya, setiap kelompok berkewajiban untuk mempresentasikan apa yang dihasilkannya di hadapan teman-teman dan dosen yang bersangkutan. Presentasi ini dimaksudkan untuk mendapatkan tanggapan 
dan masukan konstruktif dari semua pihak, baik dari teman-teman maupun dari dosen pembina yang selanjutnya ditindaklanjuti dengan evaluasi.

\section{3) Perancangan Pembelajaran}

Dosen membahas rancangan pembelajaran yang akan dilaksanakan untuk membantu peserta didik memahami masalah yang teridentifikasi.

Setelah menetapkan masalah yang akan dikaji, dosen menyusun rencana pembelajaran. Rencana pembelajaran yang tersusun meliputi ;

(1) Tujuan Pembelajaran Umum, yaitu berkenaan dengan materi pembelajaran yang menjadi pokok mata kuliah.

(2) Tujuan Khusus, berkenaan dengan masalah-masalah yang telah teridentifikasi sebelumnya.

(3) Evaluasi, evaluasi yang digunakan adalah evaluasi proses dan evaluasi hasil. Evaluasi proses dilakukan dengan mengamati perkembangan perilaku peserta didik selama pembelajaran. Evaluasi hasil dilakukan dengan mengoreksi hasil tes, memberi catatan-catatan sebagai feedback, dan mengembalikan kepada mahasiswa sebagai bahan untuk tes selanjutnya.

\section{4) Pelaksanaan Pembelajaran}

Dosen membuka pelajaran dan melakukan pengecekan terhadap kehadiran peserta didik. Dosen menjelaskan masalah-masalah yang dikaji satu persatu. Selanjutnya, masalah-masalah yang telah teridentifikasi sebelumnya.

Selanjutnya, dosen memberikan tugas kepada kelompok untuk dibahasDosen mengingatkan kepada para ketua kelompok untuk tidak menguasai jalannya kerja kelompok. Ketua kelompok harus memberi kesempatan kepada setiap anggota untuk menjawab pertanyaan dari dosen, karena penilaian akan dilakukan oleh dosen dengan cara melihat bagaimana mahasiswa menyelesaikan tugas.

Dosen berkeliling kelas untukmemantau kerjasama peserta didik sambil mencatat beberapa perkembangan yang terjadi dalam kelompok tersebut. 


\section{APLIKASI PORTOFOLIO DALAM EVALUASI PEMBELAJARAN BAHASA ARAB}

Evaluasi yang dilaksanakan dalam pembelajaran bahasa Arab berbasis portofol io ini meliputi evaluasi proses dan evaluasi hasil. Dalam evaluasi proses, dosen melaksanakan evaluasi dengan cara melihat perkembangan dan kemajuan baik yang bersifat individual maupun kelompok selama proses pembelajaran berlangsung. Hal ini dilakukan dengan cara mencatat perilaku, respon, dan aktivitas mahasiswa dari $\mathrm{p}$ ertemuan pertama sampai pertemuan terakhir. Sedangkan evaluasi hasil dilakukan dengan cara memberikan tes kepada peserta didik tentang masalah-masalah yang diidentifikasi, kemudian mengoreksi dengan memberikan catatan perbaikan sebagai feedback, selanjutnya mengembalikan hasil koreksian tersebut kepada peserta didik untuk dipelajari guna mempersiapkan tes berikutnya.

Pada tes pertama, dosen mengoreksi hasil kerja peserta didik dan memberikan beberapa catatan yang perlu diperbaiki oleh peserta didik sekaligus sebagai feedback bagi mereka. Catatan-catatan tersebut dimaksudkan agar mahasiswa mengetahui kesalahan yang diperbuatnya dan tidak mengulanginya pada tes berikutnya dalam masalah yang sama. Penilaian ini didasarkan pada acuan atau kaidah-kaidah yang telah ditetapkan sebelumnya.

\section{Kendala-kendala Aplikasi Portofolio dalam Pengajaran Bahasa Arab}

Pada aplikasi portofolio dalam pembelajaran dan evaluasi pengajaran bahasa arab menemui beberapa kendala. Kendala-kendala dijelaskan sebagai berikut.

1. Memerlukan kerja keras dan alokasi waktu yang lama

Portofolio memerlukan waktu yang lama baik ketika tahap persiapan maupun pengecekan dan penilaian. Pada tahap persiapan, banyak guru yang mengeluhkan kesulitan merancang portofolio yang baik. Mereka merasa bahwa untuk membuat rancangan portofolio memerlukan kerja keras dan ketelitian ekstra.

Karena portofolio perlu dikoreksi dan diberikan feed back, maka pada tahap penilaian, portofolio juga memerlukan waktu dan ketelitian. 


\section{Kelas yang heterogen}

Setiap dosen menginginkan anak didik yang memiliki kemampuan yang merata karena lebih mudah dikelola. Namun sayang, tidak semua mahasiswa memeliki kemampuan yang sama. Hal ini dikarenakan latar belakang mahasiswa yang beragam. Portofolio sendiri akan lebih mudah diterapkan di kelas homogen, namun bukan berarti ia tidak cocok untuk kelas yang heterogen. Banyak pakar menyarankan agar portofolio diterapkan di kelas yang heterogen karena sifatnya yang terbuka (open-ended). Dengan sifat seperti ini, setiap mahasiswa memeiliki kesempatan untuk menunjukkan karya terbaiknya sesuai dengan kemampuan yang dimilikinya. Dengan demikian dosen lebih mudah mengamati kelebihan dan kekurangan setiap mahasiswanya. Dosen juga dapat selalu memonitor perkembangan setiap mahasiswanya. Mahasiswa yang memiliki kelebihan diberi kesempatan untuk menunjukkan kemampuan terbaiknya sementara mahasiswa yang lemah diberi motivasi untuk mencapai prestasi yang maksimal. Karena itu, tidak ada portofolio yang sama persis karena kemampuan mahasiswa juga berbeda-beda.

\section{Koreksi oleh mahasiswa terkadang kurang objektif}

Dalam portofolio mahasiswa terkadang dilibatkan dalam pengoreksian. Masalah yang muncul adalah apakah hasil koreksi mahasiswa tersebut dapat diandalkan? Bahkan terkadang dijumpai mahasiswa yang menyalahkan karya temannya karena tidak tahu atau karena sengaja.

Perlu diingat bahwa keterlibatan mahasiswa dalam pengkoreksian dimaksudkan untuk membuat mahasiswa lebih memahami materi yang diberikan dan melatih tanggung jawab. Dengan demikian tidak ada hal yang harus dirisaukan. Yang harus dipersiapkan oleh dosen adalah memberi penjelasan secara detail kriteria-kriteria penilaian agar mahasiswa mampu menilai karya temannya sesuai dengan kriteria yang telah disepakati.

\section{Kurangnya sarana}

Dalam penerapan penilaian portofolio memerlukan sarana yang memadai. Salah satu di antaranya adalah rak penyimpan file para mahasiswa. Karya mahasiswa harus disimpan dengan baik agar tidak tercecer atau hilang. Setiap mahasiswa harus memiliki satu file yang berisi karya terbaiknya dari waktu ke waktu untuk disimpan dengan baik. Ini dimaksudkan agar karya mahasiswa tersebut dapat selalu dilihat dan dimonitor perkembangannya baik oleh dosen maupun mahasiswa sendiri. Untuk itu, perlu disediakan rak atau locker untuk menyimpannya. 


\section{e. Terkadang sulit mengetahui karya asli mahasiswa}

Karena tidak setiap karya mahasiswa dikerjakan di kelas, maka sulit rasanya bagi dosen untuk mengetahui apakah karya yang dikumpulkan dalan file itu karya pribadi atau karya orang lain. Terkadang mahasiswa tidak jujur terhadap dirinya sendiri, yakni minta tolong orang lain untuk mengerjakan tugasnya. Untuk menghindari kendala ini, dosen hendaknya memberikan penjelasan s ecara detail $t$ ujuan portofolio a gar mahasiswa mengerjakan tugasnya sendiri. Di samping itu, dosen juga hendaknya memberikan tugas yang harus selesai di kelas agar dosen mampu membedakan antara karya sendiri mahasiswa dan karya orang lain.

\section{f. Kurangnya perhatian penyelenggara}

Keberhasilan suatu program biasanya tidak terlepas dari orang yang memegang kendali kekuasaan. Dalam hal ini, tentu kepala pogram memiliki andil besar dalam suksesnya penerapan portofolio. Peranan lembaga untuk ikut menyedikan sarana dan prasarana sangat dibutuhkan untuk menunjang keberhasilan penerapan penilaian portofolio. Misalnya, mendukung usaha-usaha yang dilakukan dosen dengan mengusahakan locker, dan fasilitas lain seperti menambah laboratorium bahasa.

\section{E. PENUTUP}

Untuk mempertahankan irama belajar mahasiswa agar tidak menurun harus terdapat variasi proses dan cara belajar. Belajar selama satu semester di dalam kelas tanpa adanya selingan, misalnya melakukan kerja lapangan, melakukan out bond, dan sebagainya tentu akan membosankan. A pabila mahasiswa sudah merasa bosan dalam belajar, karena tidak ada variasi dan selingan, maka irama belajar peserta didik akan menurun. Model protofolio sangat efektif untuk mempertahankan irama belajar mahasiswa.

Evaluasi yang digunakan adalah evaluasi proses dan evaluasi hasil. Evaluasi proses dilakukan dengan mengamati perkembangan perilaku peserta didik selama pembelajaran. Evaluasi hasil dilakukan dengan mengoreksi hasil tes, memberi catatan-catatan sebagai feedback, dan mengembalikan kepada mahasiswa sebagai bahan untuk tes selanjutnya.

Bagi lembaga yang melibatkan diri dengan membuat model pembelajaran bahasa Arab berbasis portofolio ini menjadi program prioritas. Mengingat model pembelajaran seperti ini memerlukan dukungan dana dan sarana yang besar. Begitu juga bagi dosen yang mengembangkan penerapan portofolio dalam 
pengajaran bahasa Arab yang diasuhnya agar mampu membuat mahasiswa mencapai keberhasilan yang maksimal dan mampu menjadi contoh penerapan portofolio bagi dosen lainnya.

Begitu juga mahasiswa hendaknya mengikuti petunjuk dosen dengan sungguh-sungguh a gar protofolio y ang dikerjakan m encapai hasil y ang maksimal. Mahasiswa hendaknya tidak malas-malasan untuk membuat karya terbaiknya, baik individu maupun kelompok, untuk dimasukkan dalam file portofolio.

\section{DAFTAR PUSTAKA}

Budimansyah dan Amie Fajar. 2001. Model Pembelajaran Berbasis Portofolio Kesadaran H ukum M asyarakat . Modul Pelatihan Proyek Imtaq, Kewarganegaraan dan Budi Prkerti. Direktorat Jendral Pendidikan Dasar dan Menengah. Depdiknas.

Dahar, Ratna Wilis.1996. Teori-teori Belajar. Jakarta : Penerbit Erlangga

Budimansyah, Dasim. 2003. Model Pembelajaran Berbasis Portofolio; Pendidikan Agama Islam. Bandung: Ganesindo

Djahiri, Kosasih. 1985. Strategi Pengajaran Afektif-Nilai-Moral VCT dan Games dalam VCT. Bandung: Jurusan PMPKN FPIPS IKIP.

Djahiri; Kosaših. 2000. Model Pembelajaran Portofolio Terpadu dan Utuh. Bandung. CICED.

De Fina; A 1992. Portofolio Assessment: Getting Started. Scholastic.

Gagne, R.M. 1997. The Condition Of Learning. New York: Holt, R. and W.

Ghazali, Abd Syukur. 2000. Pemerolehan dan Pengajaran Bahasa Kedua. Depdiknas: Proyek Pengembangan Guru Sekolah Menengah.

Hakim, Thursan. 2000. Belajar Secara Efektif. Jakarta: Puspa Swara.

Johnson, J.M. 1996. Portofolio Assessment in Scond Language Teacher Education. TESOL Journal. Volume 2.

Joyce, B dan Weil, M.E. 1986. Models of Theacing. New York: Mac Milan.

Kermp, Judy \& Debby Toperoff. (Edited by Ahmad Rofi'udin). 2001. Malang: Indonesian Departement Post Graduate State University Of Malang.

Kebijakan Kurikulum berbasis kompetensi. 2001. Jakarta: Pusat Kurikulum-Badan Penelitian dan Pengembangan Departemen Pendidikan Nasional. 
Kebijakan Kurikulum berbasis kompetensi. 2002. Jakarta: Pusat Kurikulum-Badan Penelitian dan Pengembangan Departemen Pendidikan Nasional.

Larsen-Freeman, Deane dan Long, Mitchael H. 1994. An Introduction to Second Language Acquisition Research. London: Longman.

Menyuk, Paula. 1978. Language and Muturation. Combridge, Massachussetts: The MIT Press.

Menyụk, Paula.1988. Language Development, Knowledge And Use. Glenview, Illinois:

Scott, Foresman and Company.

Pulson F.L., P.R. and C.A. Mayer. 1991. What make a portofolio a portofolio? Educational Leadhership. February.

Poerwadarminta W.J.S 1976. Kamus Umum Bahasa Indonesia. Pusat Pembinaan dan Pengembangan Bahasa Dep P dan K. Jakarta PN.Balai Pustaka

Pophain, W James 1995. ClassroomAssesment; What Theacher Need to Know. United States of Ame: Allyn dan Bacon - A Simon dan Schuster Company

Rancạ́ngan Uji Coba Model Pembelajaran Berbasis Portofolio Pendidikan Kewarganegaraan d i Sekolah. 2001. Jakarta: Proyek Pendidikan Kewarganegaraan, Akhlak Budi Pekerti, Dirjen Pendidikan Dasar dan Menengah

Rancangan Perintisan Model Pembelajaran Portofolio di Delapan Propinsi. 2001. Bandung: Universitas Terbuka dan CICED

Rofi'udin, Ahmad.Dr. 1994. Ragam Tes Bahasa. Malang: IKIP Fakultas Pendidikan Bahasa dan Seni.

Rofi'udin, Ahmad.Dr. 1995. Penyususnan dan Pemvaliditasan Tes Bahasa. Malang: IKIP Fakultas Pendidikan Bahasa dan Seni.

Shaklee, D. Baverly, ..( et. al). 1977. Designing and Using Portofolio. United States of America: Allyn dan Bacon - A Simon dan Schuster Company

Santos!'M.G. 1997. Portofolio Assessment and The Role of Learner Reflection. Forum 53:2.pp. 2-9

Tieruey, J. Robert,...(et. al). 1991. Portofolio Assessment in the Reading-Writing Classroom. United States of America: Christopher - Gordon Publisher, Inc.

Tiemey R.J., M.A. Carter and L.E. Desai. 1991. Portofolio Assessment in the Reading -Writing Clascroom. Nowwood: Cristopher Gordon Publisher.

Topernof, Debby. 1995. P ortofolio Assessment in Literature Teaching. MA. Disertation. Survey University

Usman, Uzer. Moh.2000. Menjadi Guru Profesional. Bandung : Remaja Rosdakarya. 